\title{
Biological observations and first stranding record of Mesoplodon peruvianus from the central Pacific coast of Oaxaca, Mexico
}

\author{
Jesús García-Grajales ${ }^{1 *}$, Alejandra Buenrostro Silva ${ }^{2}$, Eunice Rodríguez-Rafael ${ }^{3}$, and Juan Meraz ${ }^{1}$ \\ ${ }^{1}$ Instituto de Recursos, Universidad del Mar campus Puerto Escondido. Km 2.5, Carretera Federal Puerto Escondido - Sola de Vega, \\ Puerto Escondido, CP. 71980, Oaxaca. Oaxaca, México. E-mail: archosaurio@yahoo.com.mx (JGG), sula@angel.umar.mx (JM) \\ ${ }^{2}$ Instituto de Industrias, Universidad del Mar campus Puerto Escondido. Km 2.5, Carretera Federal Puerto Escondido - Sola de \\ Vega, Puerto Escondido, CP. 71980, Oaxaca. Oaxaca, México. E-mail: sba_1575@yahoo.com.mx (ABS). \\ ${ }^{3}$ Licenciatura en Biología Marina, Universidad del Mar. Ciudad Universitaria, Puerto Ángel, Distrito de San Pedro Pochutla, CP. \\ 70902. Oaxaca, México. E-mail: niicherafael.mr@gmail.com (ER-R). \\ *Corresponding author
}

The knowledge of Mesoplodon peruvianus species about its distribution and ecology is limited, because the range of the species is unknown. Mainly due to their inconspicuous behaviour. A survey was conducted from November 2014 to January 2015 along a near 80 km long transect in the central coast of Oaxaca. Additionally, based on an stranded individual at Zicatela beach, we measured it and performed a necropsy to report the probable cause of stranding. Two individuals of $M$. peruvianus species were observed on December 5,2014 at about 9.3 $\mathrm{km}$ from the coast at 12:45 local time. The identification was clearly positive because of the black and white large individual, with an estimated size of $4 \mathrm{~m}$. This is the first record of M. peruvianus in the area. On March second 2016, a carcass of a male of M. peruvianus was found stranded at Zicatela beach; was classified as scale 2 stranded individual (freshly dead). Our main pathological findings were related with the respiratory and the digestive systems. The thoracic cavity arose out of air suggesting a pneumothorax; lungs were collapsed and to the touch showed a consistency of atelectasis. In total, 18 marine mammal species have been recorded for the state of Oaxaca, this study adds a new record, confirming the presence of $M$. peruvianus and its distribution in the region. The collapsed lungs of the stranded individual, probably resulted from an apnea state, were related with dysbarism. In Mexico no exist the practice of necropsies in wild marine mammals, therefore, our work contributes to gather relevant information on the health of marine mammals and the threats they face.

El conocimiento acerca de la distribución y ecología de Mesoplodon peruvianus es limitada debido a que su comportamiento enigmático limita el conocimiento acerca de su ámbito hogareño. Se realizaron muestreos en transectos lineales paralelos a la costa de Oaxaca de noviembre de 2014 a enero de 2015 con el fin de obtener registros de mamíferos marinos. Adicionalmente, con base en un ejemplar varado en la playa Zicatela en 2016, realizamos su medición y necropsia para indagar las posibles causas del varamiento. Dos individuos de M. peruvianus fueron avistados el 5 de diciembre de 2014 a 9.3 km de la costa alrededor de las 12:45 horas del día. La identificación se realizó por la típica coloración y se le estimó una longitud de $4 \mathrm{~m}$. Estos avistamientos son el primer registro de M. peruvianus en la zona, contribuyendo al conocimiento de la especie. El 2 de marzo de 2016, se encontró el cadáver de un ejemplar macho de M. peruvianus varado en la playa Zicatela. Se le clasificó en la escala 2 (recién muerto). Nuestros principales hallazgos patológicos se relacionaron con el sistema respiratorio y el digestivo. La cavidad toracica presentó evidencia de aire sugiriendo un pneumotorax y los pulmones estuvieron colapsados y al tacto presentaron una consistencia elástica atribuida a una posible atelectasia. En total, 18 especies de mamíferos marinos han sido registrados para el estado de Oaxaca y nuestro trabajo adiciona un nuevo registro con distribución en esta region y confirma la presencia de M. peruvianus. Respecto al ejemplar varado, los pulmones colapsados encontrados en el cadaver, probablemente sean resultado de una condición de apnea, relacionada con disbarismo. En México, no existe la práctica de las necropsias en animales de vida silvestre, por tanto, nuestro trabajo contribuye a reunir información acerca del conocimiento de la salud de los mamíferos marinos y sus amenazas.

Keywords: Cetaceans; necropsy; sightings; Zicatela; Ziphiidae.

(c) 2017 Asociación Mexicana de Mastozoología, www.mastozoologiamexicana.org

\section{Introduction}

The Ziphiidae family is one of the most wide-ranging families of cetaceans, occurring from the ice edge at both poles, to the equator in all the world's oceans (McLeod et al. 2006). However, knowledge of individual species range varies greatly, in some cases the species range is fairly well known (V. gr. Mesoplodon bidens, McLeod 2000) and some species are regularly sighted at sea (V. gr. Ziphius cavirostris, McLeod et al. 2006), while other species are almost completely unknown (V. gr. M. traversii van Helden et al. 2002; M. peruvianus McLeod et al. 2006). There is a number of reasons for this knowledge variation. First, in some species there are many distribution records obtained by trained observers during marine mammal survey cruises and by tuna purse seiners during their fishing activities (Pitman et al. 1988) or by stranding records (V. gr. M. bowdoini McLeod et al. 2006; Ziphius cavirostris Gallo-Reynoso and HoyosPadilla 2015), for other species their range is unknown due to their unknown behaviour (McLeod et al. 2006).

The pygmy beaked whale (Mesoplodon peruvianus) is one of the 14 Mesoplodon species that are present in the North Pacific Ocean (Leatherwood et al. 1982; Mead 1989; Dalebout et al. 2008), the specie was described by Reyes et al. (1991) based in the cranial characteristics, and those characteristics related to teeth (Reyes et al. 1991). Due the lack of intact specimens (only two reported then) external appearance, in terms of coloration, was limited to deep grey (biggest individual) or brown (from a calf), both with a 
grey belly (Reyes et al. 1991). Because of this relatively small body size (up to $3.7 \mathrm{~m}$ according with Reyes et al. 1991) the species has been known as the pigmy beaked whale.

A year later of the species first description, M. peruvianus was sighted in the North Pacific, at Bahia de La Paz, Mexico (Urbán-Ramírez and Aurioles-Gamboa 1992). These authors showed two important points: 1) M. peruvianus might be distributed from Peru, to Northern Mexico, possibly including all the Eastern Tropical Pacific, and 2) at that time, both Mesoplodon sp. A. and M. peruvianus were considered as two possibly species, however, this assumption continued for several years with some literature and field guides including both as separate species (Carwardine 1995; Jefferson and Leatherwood 1995; Ceballos et al. 2005).

Later, from two pigmy beaked whales stranded in La Paz, Mexico, it was possible to determine sexual dimorphism based in the shape and size of teeth (Aurioles-Gamboa and Urban-Ramirez 1993), according with the degree of development of teeth (Moore 1968). Later, based on 24 individuals of $M$. sp. A., photographed from up to 13 different sightings, important morphometric data was obtained in order to determine that this species and $M$. peruvianus share some key characteristics: short-beaked forms, tooth placed in similar position, and the same oceanic range (Pitman and Lynn 2001). These authors analysed the differences and similarities from Mesoplodon sp. A., M. peruvianus and the relatively new species $M$. bahamondi (Reyes et al. 1995), proposing that Mesoplodon sp. A. was "in fact" $M$. peruvianus (Pitman and Lynn 2001) despite the differences reported on size and colour patterns.

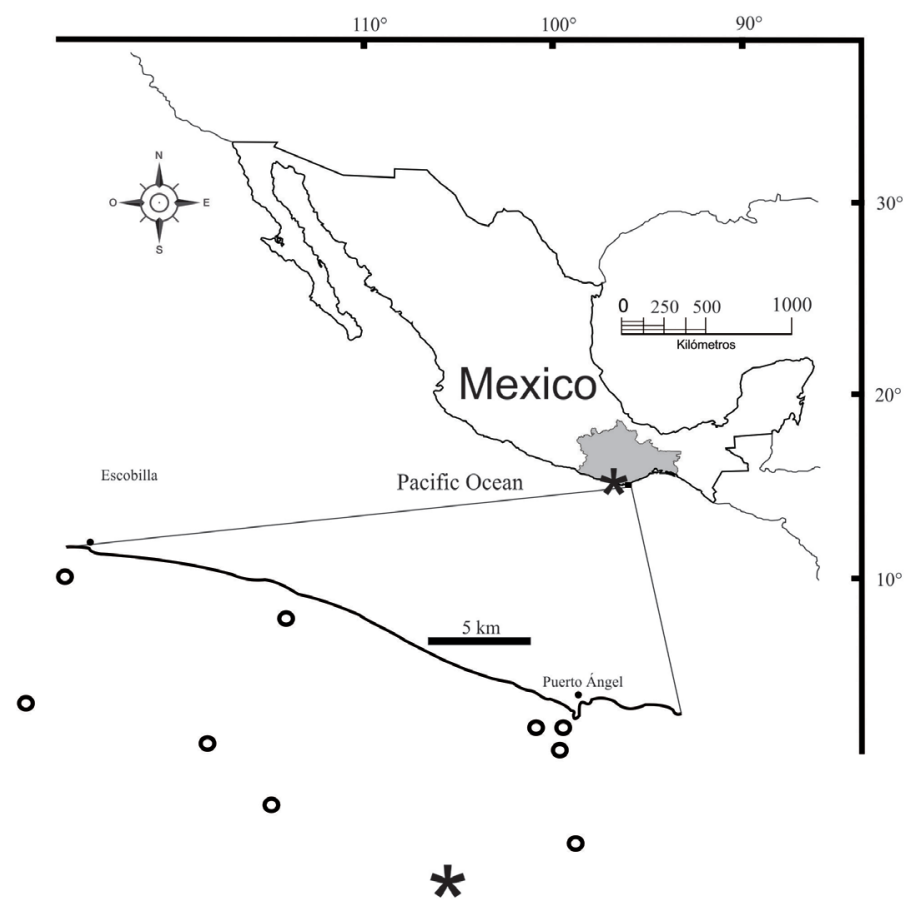

Figure 1. Location of Mesoplodon peruvianus sightings (asterisk) in the wild and male stranded (asterisk) in the Pacific coast of Mexico. Shaded area corresponds to the Mexican Estate of Oaxaca. Detailed study area shows in circles were marine mammals were sighted.
According with some literature and unpublished documents, distribution of pigmy beaked whale in Mexico was restricted mainly to the southern Gulf of California, and no individuals reported to the coast off south-western Mexico, including Oaxacan waters. From later sightings, distribution range of $M$. peruvianus has increased including waters from the central coast of Chile (Sanino et al. 2007).

Recently, a new marine mammal stranding network has started their activities in the coasts of Oaxaca, composed by volunteers of academic institution, state and federal wildlife services agencies, fishermen groups, lifeguards and other individuals who respond to or provide professional advice on handling stranding events. Ministry of Environment and Natural Resources (SEMARNAT) and Federal Attorney for Environment Protection (PROFEPA) from Oaxaca state coordinate these activities. Each stranding event is handled on a case-by-case basis between areas depending of available resources, personnel and logistics (Norman et al. 2004). This network will gather and compile information related to cetacean and other marine mammal strandings, their distribution, mortality and seasonal occurrences (e.g. Villegas et al. 2015, Hernández-Guillen 2016, Villegas-Zurita et al. 2016).

Cetacean species richness in Oaxaca includes 14 species (Meraz and Sánchez-Díaz 2001; Meraz 2003; Meraz and Becerril-Morales 2004; Lira-Torres 2007; Meraz 2007; Meraz and Sánchez-Díaz 2008; Bastida-Zavala et al. 2013; Castillejos-Moguel and Villegas-Zurita 2013; Villegas-Zurita 2015), of these Stenella attenuata, S. longirostris, Tursiops truncatus and Megaptera novaeangliae are the most common, being S. attenuata the most abundant (Meraz and Sánchez-Díaz 2008). To date no reports of any Mesoplodon species occurring at Oaxaca's coasts has been published. However, the Eastern Tropical Pacific Ocean has been surveyed exhaustively in the search of marine mammals, with most of the sightings of M. peruvianus were made in the tropical Pacific coast of Mexico, along the tropical and subtropical waters (Pitman et al. 1987), with some reports from Central America (Rodríguez-Fonseca 2001; McLeod et al. 2006), showing that this area is very important for beaked whales distribution, but there is no information about their range in the central Pacific coast of Oaxaca.

Beaked whales are widely distributed in offshore waters of all the world's oceans except the highest latitudes of the Artic. They are rarely seen at sea due to their unknown behavior, long dive capacity, and low abundances (Reeves et al. 2002). Most information on this species biology has come from stranded animals, and several species are known from only a handful of specimens. The aim of this paper is to increase the knowledge on $M$. peruvianus in the wild and on the cause of death of a pygmy beaked whale at Playa Zicatela, in the central Pacific coast of Oaxaca, Mexico.

\section{Material and methods}

Study area. The Pacific central coast of Oaxaca is located between two oceanographic regions: the Mexican region 
that includes from Cabo San Lucas (Baja California Sur), up to the limit with Tehuantepec Isthmus. Is characterized by weak and variable winds that have a direction towards the Southeast in summer, to the Northwest in winter. The centroamerican region that comprise from the Isthmus of Tehuantepec to Panama, its main feature being the influence of both the Pacific and the Atlantic winds (Meraz and Sánchez-Díaz 2008).

The pattern of oceanographic movement in the area is determined by the California current, it is cold with low salinities and high dissolved oxygen content during winter, and nor-ecuatorial current is warm with high salinity and low dissolved oxygen content during summer (PachecoSandoval 1991). Under normal conditions the area presents a temperature that varies from 25 to $30^{\circ} \mathrm{C}$ in the first 30 $\mathrm{m}$ of the water column, found South of the $33^{\circ} \mathrm{C}$ isotherm during most of the year (Vázquez-Gutiérrez et al. 1998). The thermocline is shallow, permanent, with a mixed layer at 20 $m$ depth (Pacheco-Sandoval 1991).

Biological observation. Surveys to record marine mammals and seabirds was conducted from November 2014 to January 2015 (between 8:00 and 13:00, local time) along a ca. $80 \mathrm{~km}$ transect in the central coast of Oaxaca, Mexico, from small outboard boat, navigating at low speed (10 to $30 \mathrm{~km} / \mathrm{h}$ ). Transect line represented a trip from Puerto Angel to Escobilla (a large sand beach), parallel to the coast at about 300 to $500 \mathrm{~m}$, the return trip to Puerto Angel was done at about $10 \mathrm{~km}$ from the coast (Figure 1a) following the methodology to detect and register marine mammals of Meraz and Sanchez-Díaz (2008).

When an individual was sighted, it was registered using stabilized binoculars in order to get the species identification and number of individuals. The position of the sighting was obtained with a GPS. Sea surface temperature at 5 $m$ depth, was obtained by manual CTD.

Stranding event. Based on the stranded individual at Zicatela beach near Puerto Escondido (Figure 2), Oaxaca on March 2, 2016, we made the necropsy once the individual was transported to the laboratory of Colecciones Biologicas at Universidad del Mar.

The carcass condition was determined following the scale proposed by Rowles et al. 2001, and specific measurements was taken based on Nagorsen and Peterson (1980). The species and sex was determined based on external morphology using the expertise of the examiner and various marine mammals guides (Carwardine 1995; Jefferson and Leatherwood 1995). Then, to facilitate the post mortem examination, the animal was positioned in lateral recumbency, pathological examination was conducted according to standard protocol described by Roe (2010) and by Raverty et al. (2014). The procedure included the examination of the carcass for external lesions indicative of possible trauma.

An incision was made from the caudal limit of the anus, along the dorsolateral surface of the abdominal and tho- racic cavities, ending at the level of the rostral limit with the mandibular ramus. Dissection of abdominal musculature was realized for exposure of the abdominal viscera (Rowles et al. 2001). Then, due to a cosmetic post mortem was requested, the ribs were detached at the costosternal junction to remove the thoracic wall (Raverty et al. 2014).

A systematic review of the digestive, respiratory and reproductive systems were made to evaluated macroscopic lesions. The stomach content was collected for later inspection related to pathological and parasitological examinations (Rowles et al. 2001).

For safety of the individuals involved in the post mortem examination related to the risk of human exposure to potential zoonotic pathogens, we use facemask and gloves. We made two teams to facilitate the collect of morphometric, collection of tissue and data entry (Rowles et al. 2001).

\section{Results}

Biological observations. Marine mammals were observed in ten points (Figure 1), corresponding to 36 individuals of $S$. attenuata. However, in one of these points ( $15^{\circ} 34^{\prime} 30.28^{\prime \prime}$ $\mathrm{N},-96^{\circ} 31^{\prime} 50.33^{\prime \prime} \mathrm{W}$ ) two individuals of $M$. peruvianus were observed on December 5, 2014 at about $9.3 \mathrm{~km}$ from the coast at 12:45 local time. Both individuals swam beneath the boat and their identification was positive because both were the black and white-cream large individuals, with estimated sizes of about $4 \mathrm{~m}$. During the observation, sea surface temperature was $27.2^{\circ} \mathrm{C}$, the sea calm and clear sky. Near the observation point was small boat fishing with a surface net, and seven individuals of $S$. attenuata were observed in the surroundings.

Firststranding record. Based on the length of the stranded individual of $3.49 \mathrm{~m}$, and their particular skull characteristics such as size and shape, tooth position, and synvertex configuration, and reproductive structure, among others, we determined it to be a male of $M$. peruvianus.

The carcass was classified as scale 2 (freshly dead) and during the external examination had several lesions consistent with haematomas in the head region and in part of lateral body, bruising discoloration, and presence of bloody fluid flowing through the oral cavity and in the blowhole. Respect to the haematomas of the body, it was a single lesion and occupied a large body surface as the time passed.

During the internal examination, there were no evident anomalies, such as internal lacerations, broken bones, ruptured viscera, ulcers or damaged blood vessels. However, our main pathological findings were related to respiratory and digestive systems. The thoracic cavity presented no air suggesting a pneumothorax, the lungs were collapsed and to the touch suggested a consistency with atelectasis. On the trachea and lungs, there was a certain bubbling produced by the surfactant that lubricates and prevents alveolar collapse while diving. There were no lesions on the pleura or alveoli, or foreign bodies present.

The cardiac muscle was normal in appearance and size, 


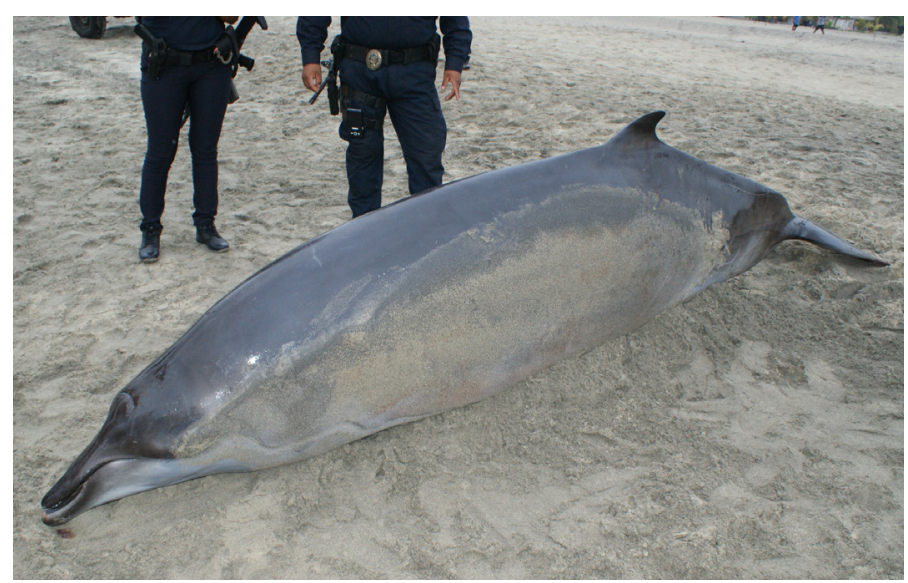

Figure 2. Mesoplodon peruvianus male stranded at Zicatela beach, Oaxaca, Mexico. March 2, 2016 (Photo Jesús García-Grajales).

no blood leaking on the surrounding vessels or the coeloms that covers it. The liver, presented no gross alterations, parasites or cists. The kidneys were observed normal in size, multilobed, no apparent haemorrhages, parasites, kidney stones or any signs of malformations. In the stomachs, ulcers, bruises or lacerations were not found, they were filled with abundant remnants of squids and shrimps exoskeletons.

\section{Discussion}

The marine mammals knowledge of the coasts of Oaxaca has increased in recent years with recent records based on occasional sightings (Meraz 2003), strandings (Meraz and Becerril-Morales 2004; Meraz 2007; Lira-Torres 2007; Villegas-Zurita 2015; Villegas-Zurita et al. 2015; 2016) and marine mammal surveys from the coast (Meraz and Sánchez-Díaz 2008). In total, 18 species have been recorded for the state of Oaxaca (Bastida-Zavala et al. 2013; Hernández-Guillen 2016) and our work add a new species with the confirmation of the presence of Mesoplodon peruvianus.

Although only two sightings on the wild are presented here, previously in the marine surveys realized during a period of over five years and the detailed report of marine mammals compiled from the central coast of Oaxaca (Meraz and Sánchez-Díaz 2008; Hernández-Guillen 2016). The presence of $M$. peruvianus had not been verified. Pitman et al. (1987) describes the behaviour of this species like other members of the genus, where its behaviour repertoire, at least when it is at the surface, appears to be limited and stereotyped. It is usually seen rolling over slowly at the surface or traveling at a moderate pace and in fairly tight groups when more than one animal is present.

Several authors have considered the limitations and possibilities of strandings information (e. g., Klinowska 1985). For instance, the proportion of species in the stranding record reflect the relative abundance of live animals of the species in the respective region and therefore, it may also reflect nothing more than a general region of occurrence and may not be related to a specific habitat preference (Norman et al. 2004), as it was the case with M. peru- vianus recorded in this work.

Another limitations of strandings are related with the physical oceanographic features that brought the carcass to shore. Surface currents and wind determine when and where an animal strands (Rice 1998). However, in this particular case the individual was found alive on the beach. Other environmental factors might influence carcass distribution: water temperature affecting decomposition rate, degree of buoyancy (e. g., some cetaceans might sink soon after death while other float) and biodegradation/scavenging of the carcass before it reaches the shore (Rice 1998).

The collapsed lungs found in the carcass, probably resulted from an apnea state, and were related with dysbarism (Binyy and Shockley 2014). This is a condition that occurs when there is a change in the surrounding pressure during a prolonged diving or moving to places of different altitudes and occur when pressure increases or decreases and includes conditions such as decompression sickness, barotraumas, nitrogen narcosis, high pressure nervous system and atrial gas embolism (Binyy and Shockley 2014).

Specific protocols for examinations and necropsies differ from examiner to examiner depending on the nature of the investigative inquiry, the experience of the examiner(s), the ultimate analysis envisioned for the samples collected, and the sizes or species involved (Norman et al. 2004). However, in Mexico no exist the practice of necropsies in wild animal, except the stranding record of Ziphius cavirostris at isla Guadalupe, Mexico (Gallo-Reynoso and Hoyos-Padilla 2015). The necropsy protocols will provide guidelines for more comprehensive necropsies and diseases (Waltzek et al. 2012) and will contribute to gathering important knowledge about the health of marine mammals and the threats they face.

\section{Acknowledgements}

The authors thanks to the Universidad del Mar for financial support to conduct the necropsy and for equipment used for ocean surveys provided by CONACYT, UMAR and SEP-PROMEP. To PROFEPA Oaxaca for the authorization (PFPA/26.3/2C2.7.3/2016).

\section{References}

Aurioles-GamboA, D., and J. Urban-Ramírez. 1993. Sexual dimorphism in the skull of the Pygmy beaked whale (Mesoplodon peruvianus). Revista de Investigación Científica 1:39-52.

Bastida-Zavala, R., S. Garcia-Madrigal, E. F. Rosas-Alquicira, R. A. López-Pérez, F. Benítez-Villalobos, J. Meraz, A. M. Torres-Huerta, A. Montoya-Márquez, and N. Barrientos-Luján. 2013. Marine and coastal biodiversity of Oaxaca, Mexico. Check-List 9:329-390. BINYY, R. L., AND L. W. SchockLEY. 2014. Scuba diving and dysbarism. Pp. 1915-1927, in Rosen's emergency medicine. Concepts and clinical practices (Marx, J. A., R. S. Hockberger, and R. M. alls, eds.). Elsevier Saunder Inc. Philadelphia, U. S. A. CARWARDINE, M. 1995. Whales, dolphins and porpoises. Eyewitness handbooks, Dorling Kindersley. London, United Kindom. 
Castillejos-Moguel, F., and F, Villegas-Zurita. 2013. Primer registro de Delphinus delphis (Mammalia: Cetartiodactyla) en la costa de Oaxaca, México. Ciencia y Mar 44:35-39.

Ceballos, G., J. Arroyo-Cabrales, R. Medellín, and Y. DominguezCastellanos. 2005. Lista actualizada de los mamíferos de México. Revista Mexicana de Mastozoología 9:21-71.

Dalebout, M. L., D. Steel, and C. S. Baker. 2008. Phylogeny of the beaked whale genus Mesoplodon (Ziphiidae: Cetacea) revealed by nuclear introns: Implications for the evolution of male tusks. Systematic Biology 57:857-875.

Gallo-Reynoso, J. P., and E. M. Hoyos-Padilla. 2015. First stranding record of a Cuvier beaked whale (Ziphius cavirostris) at Isla Guadalupe, Mexico. Therya 6:329-336.

HernÁndez-Guillen, J. J. 2016. Riqueza, incidencia y distribución espacio-temporal de varamientos de mamíferos marinos en la costa de Oaxaca, México, durante el periodo 2001-2014. Tesis de licenciatura, Universidad del Mar. Puerto Ángel, México.

Jefferson, T. A., And S. Leatherwood. 1995. Mamíferos Marinos. Pp. 1669-1745, in Pacífico Centro Oriental. Guía FAO para la identificación de especies para los fines de pesca (Fischer W., F. Krupp, C. Sommer, K. E. Carpenter, and V. H. Niem, eds.). FAO, EC, FIS, NORAD. Rome, Italy.

KLINOWSKA, M. 1985. Interpretation of the UK cetacean strandings records. Internal Report of Whale Community 35:459-467.

Leatherwood, S., R. R. Reeves, W. F. Perrin, and W. E. Evans. 1982. Whales, dolphins and porpoises of the eastern North Pacific and adjacent waters: a guide to their identification. NOAA Technical Report, MFS Circular 444: 1-245.

LIRA-TORRES, I. 2007. Nuevo registro de Balaenoptera musculus Linnaeus, 1758 (Mysticeti: Balaenopteridae) para la costa de Oaxaca, México. Revista Mexicana de Mastozoología 11:69-72.

McLeod, C. D. 2000. Species recognition as a possible function for variations in position and shape of the sexually dimorphic tusks of Mesoplodon beaked whales. Evolution 54:2171-2173.

Macleod, C., W. Perrin, R. Pitman, J. Barlow, L. D. Balance, A. Ámico, T. Gerrodette, G. Joyce, K. D. Mullin, D. L. Palka, and G. T. Waring. 2006. Known and inferred distributions of beaked whale species (Cetacea: Ziphiidae). Journal of Cetacean Research and Management 7:271-286.

MEAD, J. G. 1989. Beaked whales of the genus Mesoplodon. Pp. 349-430 in Handbokk of marine mammals (Ridgway, $\mathrm{S}$. $\mathrm{H}$., and R. Harrison, eds.). Academic Press. London, United Kindom.

Meraz, J. y V. SÁnchez-Díaz. 2001. Registro de depredación sobre Dermochelys coriacea, en las costas de Oaxaca, por Orcinus orca. Ciencia y Mar 14:51-54.

Meraz, J. 2003. Presencia de un ejemplar de lobo marino Zalophus californianus, en la costa de Oaxaca. Ciencia y Mar 21:50-53.

Meraz, J. 2007. Varamiento de un ejemplar de la estenela giradora Stenella longirostris (Gray, 1828) en Oaxaca, México. Ciencia y Mar 32:79-80.

Meraz, J., And F. Becerril-Morales. 2004. Reporte de un ejemplar varado de Pseudorca crassidens en Zipolite, Oaxaca, México. Anales del Instituto de Biología de la UNAM, Serie Zoología 71:229-235.

Meraz, J., And V. SÁnchez-Díaz. 2008. Los mamíferos marinos en la costa central de Oaxaca. Revista Mexicana de Biodiversidad 79:143-151.
MoORE, J. C. 1968. Relationships among the living genera of beaked whales, with classification, diagnoses and keys. Fieldiana Zoology 53:206-298.

Nagorsen, D. W., and R. K. Peterson. 1980. Mammal collector's manual. A guide for collecting, documenting, and preparing mammals specimens for scientific research. Royal Ontario Museum Life Science Miscellaneous, Cornel University Press. Ontario, Canada.

Norman, S. A., C. E. Bowlby, M. S. Brancato, J. Calambokidis, D. Duffield, P. J. Gearin, T. A. Gornall, M. E. Gosho, B. Hanson, J. Hodder, S. J. Jeffries, B. Lagerquist, D. M. Lambourn, B. Mate, B. Norberg. R. W. Osborne, J. A. Rash, S. Riemer, and J. Scordino. 2004. Cetacean strandings in Oregon and Washington between 1930 and 2002. Journal of Cetacean Research and Management 6:87-99.

Pacheco-Sandoval, P. 1991. Oceanografía física. Pp. 151-176, in Oceanografía de los mares mexicanos (de la lanza-Espino, G. ed.). AGT. Ciudad de México, México.

Pitman, R. L., A. Aguayo, and J. Urbán. 1987. Observations of an unidentified beaked whale (Mesoplodon $s p$ ) in the Eastern Tropical Pacific. Marine Mammal Science 3:345-352.

Pitman, R. L., D. W. K. Au, M. Scott, And J. M. Scott. 1988. Observations of beaked whales (Ziphiidae) from the eastern tropical Pacific Ocean. Paper SC/40/SM/14 - Scientific Comitee of the IWC Annual Meeting.

Pitman, R. L., And M. S. Lynn. 2001. Biological observations of an unidentified mesoplodont whale in the eastern tropical Pacific and probable identity Mesoplodon peruvianus. Marine Mammal Science 17:648-657.

Raverty, S. A., J. K. Gaydos y J. A. Leger. 2014. Killer whale necropsy and disease testing protocol. Technical Report, NOAA/NMFS/ PIRO. U.S. A

Reeves, R. R., S. S. Brent, P. J. Clapham, J. A. Powel, and P. A. Folkens. 2002. National audubon society guide to marine mammals of the world. Chanticleer Press, New Yok.

Reyes, J. C., J. G. Mead, and K. van Waerebeek. 1991. A new species of beaked whale Mesoplodon peruvianus sp. N. (cetacean: Ziphiidae) from Peru. Marine Mammal Science 7:1-24.

Reyes, J. C., K. van Waerebeek, J. C. Cárdenas, and J. L. Yáñez. 1995. Mesoplodon bahamondi sp. n. (Cetacea, Ziphiidae), a new living beaked whale from the Juan Fernández Archipelago, Chile. Boletín del Museo Nacional de Historia Natural de Chile 45:31-44.

RICE, D. W. 1998. Marine mammals of the world. Systematic and distribution. Special Publication No. 4. The Society for Marine Mammalogy. Allen Press. Lawrences, U. S. A.

Rodríguez-FonsecA, J. 2001. Diversidad y distribución de los cetáceos de Costa Rica (Cetacea: Delphinidae, Physeteridae, Ziphiidae y Balaenopteridae). Revista de Biologia Tropical 49:135-143.

RoE, W. D. 2010. Necropsy of marine mammals captures in New Zealand fisheries in the 2008-09 fishing year. New Zealand Aquatic and Biodiversity Report 47:1-22.

Rowles, T. K., M. Frances, and A. Hohn. 2001. Gross necropsy and specimen collection protocols. Pp. 449-470, in CRC Handbook of Marine Mammal Medicine (Dierauf, L. A., and F. M. Gulland, eds). CRC Press. Boca Raton, U. S. A.

Sanino, G. P., J. L. Yañez, and K. van Waerebeek. 2007. A first confirmed specimen record in Chile, and sightings attributed to the lesser beaked whale Mesoplodon peruvianus Reyes, 
Mead and van Waerebeek, 1991. Boletin del Museo Nacional de Historia Natural, Chile 56:89-96.

Urban-Ramírez, J., and D. Aurioless-Gamboa. 1992. First record of the pigmy beaked whale Mesoplodon peruvianus in the North Pacific. Marine Mammal Science 8:420-425.

van Helden, A. L., A. N. Baker, M. L. Dalebout, J. C. Reyes, K. Van WAEREBEEK, AND C. S. BAKER. 2002. Resurrection of Mesoplodon traversii (Gray, 1874), senior synonym of M. bahamondi Reyes, Van Waerebeek, Cárdenas and Yañez, 1995 (Cetecea: Ziphiidae). Marine Mammals Science 18: 609-621.

Vazquez-Gutiérrez, F., S. López, A. Ramírez, M. Turner, F. Castillo, and A. VALDÉs. 1998. La química del agua. Pp. 35-50, in El golfo de Tehuantepec: el ecosistema y sus recursos (Tapia-García, ed.). Universidad Autónoma Metropolitana. Ciudad de México, México.

VILLEGAS-ZuRITA, F. 2015. Primer registro de Steno bredanensis (Cetartiodactyla: Delphinidae) en la costa de Oaxaca, México. Therya 6:483-488.

Villegas-Zurita, F., F. Castillejos-Moguel, and F. R. ElorriagaVERPLANCKEN. 2015. Southernmost presence of the Guadalupe fur seal (Arctocephalus townsendi) in the Mexican South Pacific. Revista Mexicana de Biodiversidad 86:1107-1109.

Villegas-Zurita, F., F. R. Elorriaga-Verplancken, And F. Castillejos-Moguel. 2016. First report of a SouthAmerica fur seal (Arctocephalus australis) in Mexico. Aquatic Mammals 42:42-46.

Waltzek, T. B., G. Cortés-Hinojosa, J. F. X. Wellehan, and G. C. Gray. 2012. Marine mammal zoonoses: A review of disease manifestations. Zoonoses and Public Health 59:521-535

Associated editor: Juan Pablo Gallo

Submitted: October 2, 2016; Reviewed: March 29, 2017;

Accepted:May 8, 2017; Published on line:May 26, 2017. 